\title{
Hydrological behaviour of vertisols in the Brazilian semi-arid region: the importance of rainfall of less than $30 \mathrm{~mm}^{1}$
}

\section{Comportamento hidrológico de vertissolos no semiárido brasileiro: importância das precipitações menores que $30 \mathrm{~mm}$}

\author{
Eunice Maia de Andrade², Rafael do Nascimento Rodrigues³, Helba Araújo de Queiroz Palácio ${ }^{4}$ José Bandeira \\ Brasil $^{3 *}$, Maria João Simas Guerreiro ${ }^{5}$
}

\begin{abstract}
The greater probability of small rainfall events occurring in semi-arid regions, and the little understanding of their role in hydrological processes, has led to this investigation of surface runoff generated during these events in two adjacent micro basins in the Brazilian semi-arid region. The types of plant cover to be investigated were the Phytogeographical Caatinga Domain under regeneration for 35 years (CPDReg) and thinned CPD (CPDThin), which consisted of the elimination of trees with a diameter of $<10 \mathrm{~cm}$. Two historical series were considered, one of 40 years (1974-2013) with 2,259 events and the other consisting of 247 rainfall events of $<30 \mathrm{~mm}$ from 2009 to 2013 . The cumulative frequency distribution showed that the series of 247 24-hour events proved to be statistically representative in investigating hydrological processes in the Brazilian semi-arid region, compared to the long series of 2,259 events. Irrespective of the pattern, rainfall with an intensity of less than $17 \mathrm{~mm} \mathrm{~h}^{-1}$ generated effective precipitation with small depths $(<2 \mathrm{~mm})$. Regardless of the rainfall pattern, the lowest effective precipitation was registered for the plant cover of thinned CPD, both on an annual scale and per event. The occurrence of 3 or 4 consecutive dry days is enough for events of $<30 \mathrm{~mm}$ to generate no runoff, due to the appearance of micro-cracks formed in vertisols during the drying process. It is believed, therefore, that the expansion and contraction of vertic soils is the main determinant for the start of Pe in areas with a water source (micro basins of <2 ha) in the CPD.
\end{abstract}

Key words: Eco-hydrological processes. Seasonally Dry Tropical Forest. Thinning. Surface runoff. Rainfall patterns.

RESUMO - A maior probabilidade de ocorrências de eventos de baixa altura pluviométrica e o pouco conhecimento desses no entendimento dos processos hidrológicos em regiões semiáridas, nos conduziu a investigar a geração de escoamento superficial oriundo desses eventos em duas microbacias adjacentes no semiárido brasileiro. As coberturas vegetais investigadas foram: Domínio Fitogeográfico da Caatinga em Regeneração a 35 anos (CPD Regeneração) e CPD-Raleada, que consistiu na eliminação de árvores com diâmetro < 10 cm. Considerou-se duas séries históricas, uma de 40 anos (1974-2013) com 2259 eventos e outra composta por 247 eventos pluviométricos < $30 \mathrm{~mm}$ no período de 2009 a 2013. A distribuição de frequência acumulada mostrou que uma série de 247 eventos de 24-horas mostrou-se estatisticamente representativa em investigação de processos hidrológicos no semiárido brasileiro, quando comparado com uma série longa de 2259 eventos. Independente do padrão, chuvas com intensidades inferiores a $17 \mathrm{~mm} \mathrm{~h}^{-1}$ geraram precipitações efetivas com baixas lâminas $(<2 \mathrm{~mm})$. As menores precipitações efetivas foram registradas na cobertura vegetal CPD Raleada, independentemente do padrão da chuva, tanto na escala anual como por evento. A ocorrência de 3 ou 4 dias secos consecutivos são suficientes para que eventos $<30 \mathrm{~mm}$ não gerem escoamento devido ao surgimento das microfendas formadas no processo de secamento dos vertissolos. Portanto, acreditamos que a expansão e contração dos solos vérticos seja o principal fator determinante do início da Pe em áreas de nascentes (microbacias < 2 ha) em CPD-Caatinga.

Palavras-chave: Processos ecohidrológicos. Floresta Tropical Sazonalmente Seca. Raleamento. Escoamento superficial. Padrões de chuva.

DOI: $10.5935 / 1806-6690.20200029$

* Author for correspondence

Received for publication 04/06/2019; approved on 04/02/2020

Trabalho extraído da Dissertação de mestrado do segundo autor, apresentada ao Programa de Pós-Graduação em Engenharia Agrícola, Universidade Federal do Ceará

${ }^{2}$ Departamento de Conservação de Solo e Água, Universidade Federal Rural do Semi-Árido/UFERSA, Bolsista PQ-1A, Mossoró-RN, Brasil, eandrade.ufc@gmail.com (ORCID 0000-0002-9750-0364)

${ }^{3}$ Departamento de Engenharia Agrícola, Universidade Federal do CearáUFC, Campus do Pici, Fortaleza-CE, Brazil, rafaelnr_tid@hotmail.com (ORCID 0000-0003-4274-1328), josebbrasil@ gmail.com (ORCID 0000-0003-4335-7838)

${ }^{4}$ Departamento de Educação, Instituto Federal do Ceará, Iguatu-CE, Brazil; helbaraujo23@yahoo.com.br (ORCID 0000-0002-5105-4821)

${ }^{5}$ FP-ENAS, Universidade Fernando Pessoa, Praça 9 de Abril, 349, Porto, Portugal, mariajoao@ufp.edu.pt (ORCID 0000-0001-6774-9348) 


\section{INTRODUCTION}

Semi-arid regions correspond to one third (22.6 $\mathrm{x} 10^{6} \mathrm{~km}^{2}$ ) of all dry land, which covers approximately $41.3 \%$ of the world's surface. The semi-arid regions support a population of two billion people (REYNOLDS et al., 2007), 90\% of whom live in developing countries (UNITED NATIONS ENVIRONMENT PROGRAMME, 2007). Around $50 \%$ of the population living in these regions obtain their basic needs (water, food, fibre, energy, etc.) from the goods and services generated by the ecosystem (UNITED NATIONS ENVIRONMENT MANAGEMENT GROUP, 2011). Dry lands (aridity index $<0.65$ ) are characterised by a water deficit, which is aggravated by climate change (WOLDESENBET et al., 2018), where a higher frequency of extreme events is predicted (MARENGO; TORRES; ALVES, 2017) with an increase in the number of consecutive dry days (GUERREIRO et al., 2013).

The search for greater soil water storage in the face of climate change requires a better knowledge and understanding of hydrological processes in dry regions where there is a predominance of intermittent and/or ephemeral watercourses (CAMARASA-BELMONTE, 2016; OWUOR et al., 2016). The study of hydrological processes began in humid regions, where watercourses show perennial runoff (BARTON, 2015). Despite studies focused on the hydrology of semi-arid regions having intensified in recent decades (CAMARASA-BELMONTE, 2016; FIGUEREDO et al., 2016; RODRIGUES et al., 2013; SANTOS et al., 2016), there are few hydrological series of data obtained in the field concerning the effective precipitation of springs, initial abstraction, erosion, sediment transport, or the behaviour of extreme events (maximum and minimum, the occurrence of consecutive dry days) in dry regions with a predominance of ephemeral and intermittent watercourses.

Precipitation is the most dynamic factor affecting hydrological response in a hydrographic basin, whether due to the rainfall pattern (GUAN; SILLANPÄ̈̈; KOIVUSALO, 2016; LIMA et al., 2013; MEHL et al., 2001), rainfall depth (FANG et al., 2012; GUERREIRO et al., 2013; PENG; WANG, 2012) or rainfall intensity (BRASIL et al., 2018; JOST et al., 2012; RAN et al., 2012; SANTOS et al., 2016). However, authors like Pathak et al. (2013), have shown that vertic soils, common in dry regions, are determinants of hydrological response, due to the presence of expansive clays that promote the occurrence of cracks and micro-cracks in the soil.

Uncertainty as to how a hydrographic basin responds to a rainfall event in tropical semi-arid regions has led to studies by authors such as Almeida, Oliveira and Araújo (2012) and Santos et al. (2016), who identified rainfall thresholds that always generate runoff. There are studies aimed at understanding the ecological role of small rainfall events in dry regions (PETRIE; COLLINS; LITVAK, 2015); however, research into understanding the occurrence of surface runoff from small rainfall depths is necessary, since surveys by Almeida, Oliveira and Araújo (2012), Figueiredo et al. (2016) and Santos et al. (2016), developed in the semi-arid region of Brazil, have failed to establish an unequivocal relationship.

Andrade et al. (2018) showed that in two adjacent micro basins (one under regeneration for 35 years and the other subjected to thinning) in vertic soils, only runoff generated by rainfall of $<30 \mathrm{~mm}$ was statistically significant. The publications of Andrade et al. (2018) and Santos et al. (2016) raised the following question: what is the hydrological behaviour of ephemeral micro basins in vertic soils at rainfall depths of $<30 \mathrm{~mm}$ and with different patterns? Given this question, the aim of this study was to investigate the generation of surface runoff from rainfall of $\leq 30 \mathrm{~mm}$ with different patterns in two adjacent micro basins with vertisols in the semiarid region of Brazil, submitted to two types of plant cover.

\section{MATERIAL AND METHODS}

\section{Description of the area}

The study was conducted in two experimental micro basins located in the semi-arid region of the northeast of Brazil. The sample units are inserted in an area of public domain under the responsibility of the Federal Institute of Education, Science and Technology of Ceará (IFCE), Iguatu Campus (Figure 1). According to Köppen, the climate in the region is of type BSh (hot semi-arid), with a mean monthly temperature always greater than $18^{\circ} \mathrm{C}$ during the coldest month. The Aridity Index, proposed by Thornthwaite, is 0.44 , classifying it as semi-arid. The mean potential evapotranspiration is $1829.5 \mathrm{~mm}$ year $^{-1}$, based on the Penman-Monteith/FAO method. The mean historical rainfall in Iguatu is $883 \pm$ $303 \mathrm{~mm}$. The rainfall has a unimodal distribution, with $84 \%$ of the total registered from January to May, and $43 \%$ of events occurring between March and April (BRASIL et al., 2018).

The experimental area consists of two adjacent micro-basins (Figure 1), with first- and second-order ephemeral watercourses and moderate slope. The soil of the experimental area in both micro-basins was classified as a typical carbonatic Ebanic Vertisol with a high concentration of clay and silt (Table 1). After the collection and analysis of soil samples, the predominance 
Figure 1 - Location of the study area

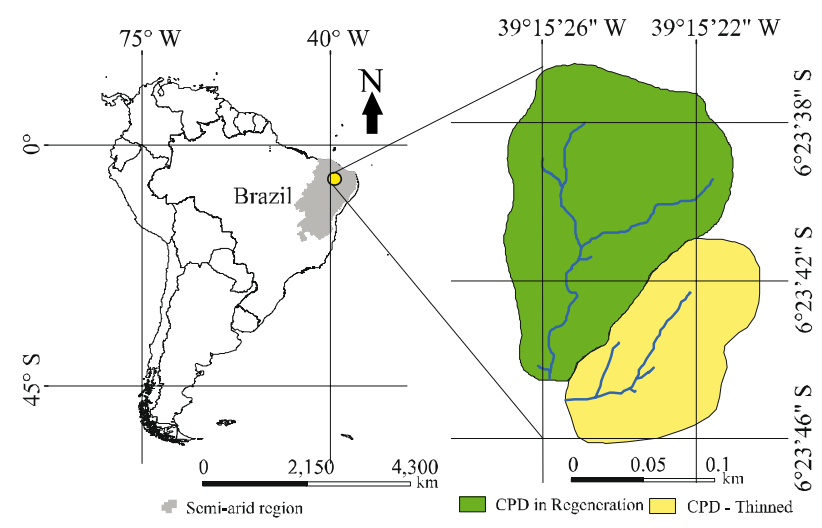

of a 2:1 expansive clay mineral of the montmorillonite group was confirmed using nuclear techniques of X-ray diffraction and fluorescence with the aid of the X'PERT HighScore Plus software (PW3212), at the Physics Laboratory of the Federal University of Ceará. Due to the type of clay present in the soils, it is common for cracks and micro-cracks to appear on the surface during the dry season, with saturation occurring during the rainy season. This process promotes high levels of infiltration, especially for early events during the rainy season.
The composition of the vegetation is typically Caatinga Phytogeographical Domain (CPD), and varies from herbaceous to tree and shrub species, typically deciduous and xerophilous, with a wide variety of thorny species (PEREIRA JÚNIOR et al., 2016).

The first micro basin was maintained with plant cover under regeneration and with no interference for 35 years, up to 2013 (Figure 2A). The plant cover in the second micro-basin was thinned by $40 \%$ (Figure $2 \mathrm{~B}$ ), where trees with a diameter of less than $10 \mathrm{~cm}$ were eliminated, as per a method adapted from Araújo Filho (1992). The management of thinning can be adopted to produce pasture (ARAÚJO FILHO, 1992), reduce surface runoff (RODRIGUES et al., 2013), reduce the erosive process (SANTOS et al., 2017) and promote sustainability of the Caatinga (ANDRADE et al., 2020; PALÁCIO et al., 2013).

The vegetation was subjected to a management of thinning in 2009, 2011 and 2013 (ANDRADE et al., 2018). This management afforded greater light penetration with the consequent development of the herbaceous layer (OWUOR et al., 2016; RODRIGUES et al., 2013). Other morphometric characteristics of the experimental micro basins under study can be seen in (Table 2).

\section{Data collection}

Two series of daily hydrological data were used. The first was a 40-year historical series (1974-2013)

Table 1 - Physical and chemical properties of the soil and \% plant cover in the two micro basins

\begin{tabular}{|c|c|c|c|c|}
\hline \multirow{3}{*}{ Soil attribute } & \multicolumn{4}{|c|}{ Management applied } \\
\hline & \multicolumn{2}{|c|}{ CPDReg } & \multicolumn{2}{|c|}{ CPDThin } \\
\hline & $0-20 \mathrm{~cm}$ & $20-40 \mathrm{~cm}$ & $0-20 \mathrm{~cm}$ & $20-40 \mathrm{~cm}$ \\
\hline $\mathrm{pH}$ & 6.92 & 6.72 & 6.70 & 6.78 \\
\hline Density $\left(\mathrm{g} \mathrm{cm}^{-3}\right)$ & 1.37 & 1.33 & 1.36 & 1.47 \\
\hline $\mathrm{Ca}\left(\mathrm{g} \mathrm{dm}^{-3}\right)$ & 284.58 & 292.32 & 300.81 & 332.38 \\
\hline $\mathrm{Na}\left(\mathrm{g} \mathrm{dm}^{-3}\right)$ & 21.84 & 21.86 & 16.16 & 28.32 \\
\hline $\mathrm{P}\left(\mathrm{g} \mathrm{dm}^{-3}\right)$ & 11.63 & 6.66 & 45.79 & 57.00 \\
\hline $\mathrm{CEC}\left(\mathrm{mmol}_{\mathrm{c}} \mathrm{dm}^{-3}\right)$ & 388.29 & 404.89 & 381.72 & 451.33 \\
\hline $\mathrm{ON}\left(\mathrm{g} \mathrm{kg}^{-1}\right)$ & 0.88 & 0.28 & 1.48 & 1.25 \\
\hline Sand $(\%)$ & 18.40 & 17.76 & 12.42 & 15.94 \\
\hline Silt (\%) & 33.75 & 37.30 & 38.15 & 32.55 \\
\hline Clay (\%) & 47.85 & 44.94 & 49.43 & 51.51 \\
\hline Textural class & \multicolumn{2}{|c|}{ Clayey } & \multicolumn{2}{|c|}{ Clayey } \\
\hline \multicolumn{5}{|c|}{ Plant cover } \\
\hline Crown cover $(\%)$ & \multicolumn{2}{|c|}{90} & \multicolumn{2}{|c|}{60} \\
\hline Herbaceous cover $(\%)$ & \multicolumn{2}{|c|}{30} & \multicolumn{2}{|c|}{100} \\
\hline
\end{tabular}

CPDReg - Caatinga Phytogeographical Domain under regeneration; DFEThn - Caatinga Phytogeographical Domain submitted to thinning 
Figure 2 - Details of the vegetation in the two micro basins during the rainy season: (A) CPDReg; (B) CPDThin

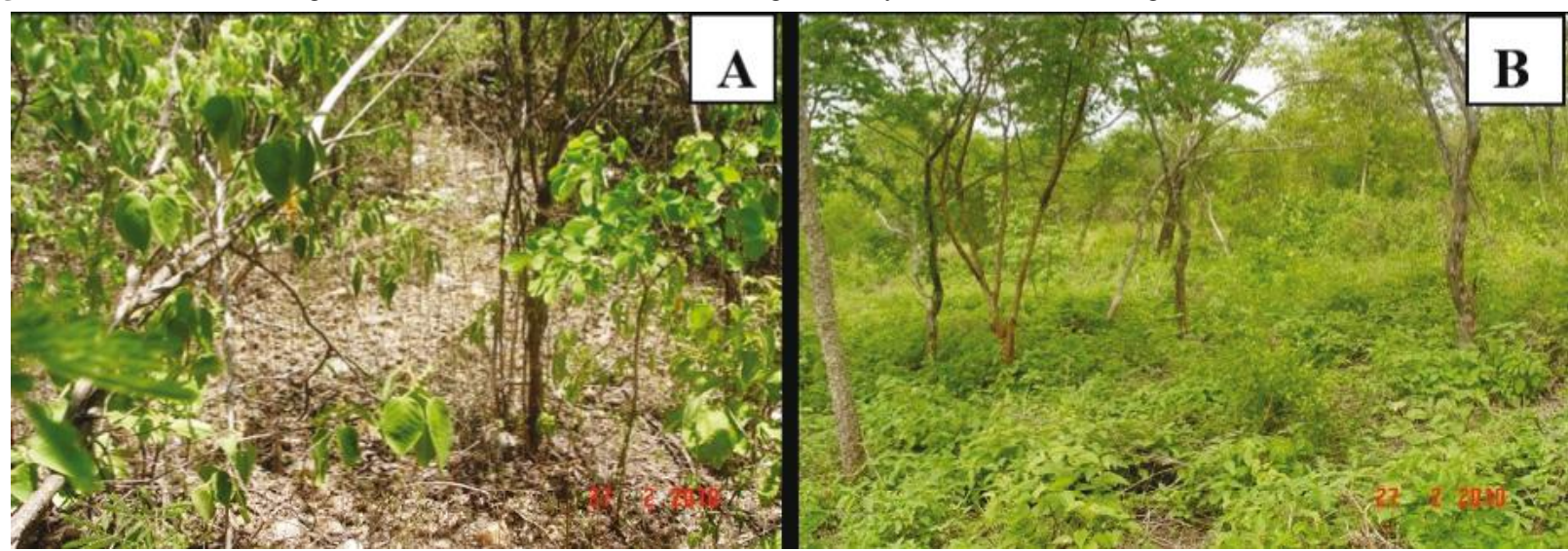

Source: Eunice Maia de Andrade

Table 2 - Morphometric characteristics of the two micro basins

\begin{tabular}{cccc}
\hline Variable & CPDReg & CPDThin & Unit \\
\hline Area of the basin $(\mathrm{Ab})$ & 2.06 & 1.15 & ha \\
Perimeter $(\mathrm{P})$ & 594.50 & 478.35 & $\mathrm{~m}$ \\
Length of the main watercourse. (Lmw) & 252.11 & 147.18 & $\mathrm{~m}$ \\
Length of the basin (Lb) & 204.20 & 188.17 & $\mathrm{~m}$ \\
Slope of the basin $(\mathrm{Sb})$ & 10.59 & 8.72 & $\%$ \\
\hline
\end{tabular}

Fonte: autor

comprising 2,259 24-hour rainfall events, which were obtained from the FUNCEME website, this was known as the long-term series. The second series consisted of 247 daily rainfall and runoff events over a period of 5 years (2009-2013), known as the short-term series. The longterm series was used to characterise the rainfall in the study region.

Based on the short-term series, all rainfall events with a rainfall of $\leq 30 \mathrm{~mm}$ were selected. This threshold was chosen based on results obtained by Andrade et al. (2018) and Santos et al. (2017). Hydrological monitoring of the micro basins was carried out by automatic stations, with recordings taken every five minutes. The rainfall data were obtained with a bascule rain gauge, and the runoff data via a calibrated Parshall gutter equipped with an automatic linigraph (capacitive sensors), both calibrated in the field.

\section{Data analysis}

In order to identify the hydrological similarity of the two series, and to ascertain whether the short-term series could be considered representative for studies on the scale of rainfall events, the cumulative daily frequency of the two historical rainfall series was developed. To better visualise the distribution of the data, a quartile distribution was generated using box-plot graphs. After classifying the rainfall events according to rainfall pattern, they were compared to the maximum rainfall intensity and consecutive dry days (CDD). The method developed by Mehl et al. (2001) was used to identify the rainfall pattern, where the rainfall events are classified into the following patterns: early, intermediate and late, according to the position of the peak of greatest intensity (maximum intensity over $5 \min -\mathrm{I}_{5} \max$ ).

\section{RESULTS AND DISCUSSION}

\section{Long-term and short-term analysis}

The cumulative frequency distribution of 24hour rainfall for both series, long-term (1974-2013) and short-term (2009-2013), showed a log-normal cumulative frequency distribution (Figure 3), a similar distribution pattern (Figure 4A), and statistically equal median values (Figure 4B) at a significance level of 5\% $(\mathrm{p}<0.0075)$ with equal variances $(\mathrm{p}<0.000)$. These results showed that 
the short-term series, comprised of 247 24-hour events, is statistically representative for hydrological studies in tropical semi-arid regions of CPD. Based on the 40-year series as well as the five-year series, it was found that $75 \%$ of the 24-hour rainfall events were equal to or less than 30 $\mathrm{mm}$ (Figures 3 and $4 \mathrm{~B}$ ), as well as the constant occurrence of extreme events, i.e. $\mathrm{P}>1.5^{*}\left(\mathrm{Q}_{3}-\mathrm{Q}_{1}\right)$ in each series.

It was also found that rainfall events greater than $52 \mathrm{~mm}$ are outside the $95 \%$ confidence interval (Figure 3 ), and as such are classified as outliers. The largest outlier was registered in the long-term series, with a rainfall depth of $170 \mathrm{~mm}$ in 1980, and the second largest of $140 \mathrm{~mm}$ in 2013, and was present in both series (Figure 4B). Due to the size of the historical series, the greatest number of outliers was registered in the long-term series, however, both series showed a similar distribution (Figures 3 and 4, and Table 3 ).

Figure 3 - Distribution of 24-hour rainfall events in Iguatu, Ceará

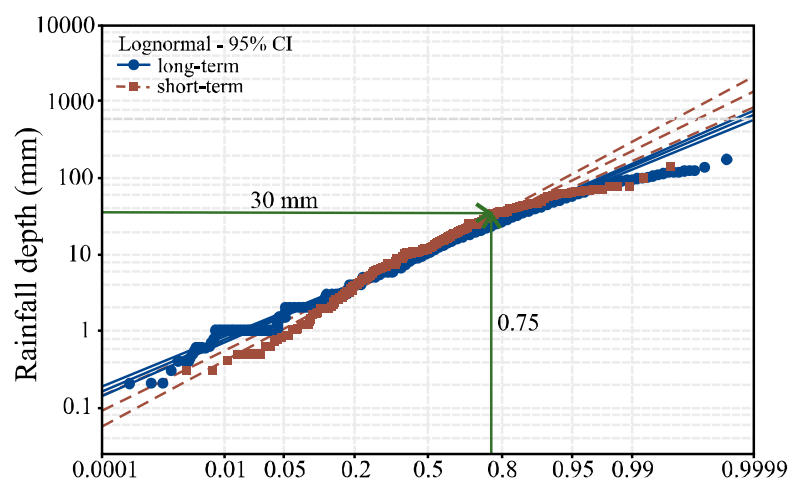

Probability of less than or iqual ordinate number
The high number of discrepant events is due to the rainfall regime in the region, which is characterised by the presence of extreme events (GUERREIRO et al., 2013) and a high frequency of small events (Figures 3, 4 and Table 4), as identified by Andrade et al. (2018). The high frequency of events of less than or equal to $30 \mathrm{~mm}$ (Q3) shows the need to investigate how they contribute to generating surface runoff, given the rainfall pattern.

For the short-term series (2009-2013), the rainfall that occurred during the rainy season demonstrated the variability of the rainfall regime in the region (Table 4). It was found that during 2011, the rainfall depth was $98 \%$ and 100\% higher than during 2010 and 2013 respectively. The uncertainty of the hydrological regime is a characteristic of semi-arid regions, where the high temporal variability of the rainfall events predominates (CAMARASABELMONTE, 2016; GUERREIRO et al., 2013). Of the 247 rainfall events that occurred, 53\% were registered during 2009 and 2011, years with rainfall above the average for the region $(883 \mathrm{~mm})$. The remaining $46 \%$ had the following distribution: $17,15.4$ and $14.6 \%$ for 2010 , 2012 and 2013 respectively, indicating the occurrence of three dry years alternating with two wet years.

Depending on the rainfall characteristics number of events and total depth) and their spatial distribution, it is possible for an annual rainfall depth of $660 \mathrm{~mm}$ not to generate surface runoff, as seen in 2013 (Table 4). Although 75\% of the events (Q3) are $<30 \mathrm{~mm}$ (Table 3), they account for $34 \%(1552.1 \mathrm{~mm})$ of the precipitated depth (Table 4). The Pe generated by events of $<30 \mathrm{~mm}$ in relation to the total Pe represents $21 \%(72.2 / 339.5)$ and $14 \%(36.2 / 251.7)$ for the micro basins in CPDReg and CPDThin respectively. These smaller run-off depths can

Figure 4 - Frequency distribution of the 24-hour events and comparison of the average of the two series
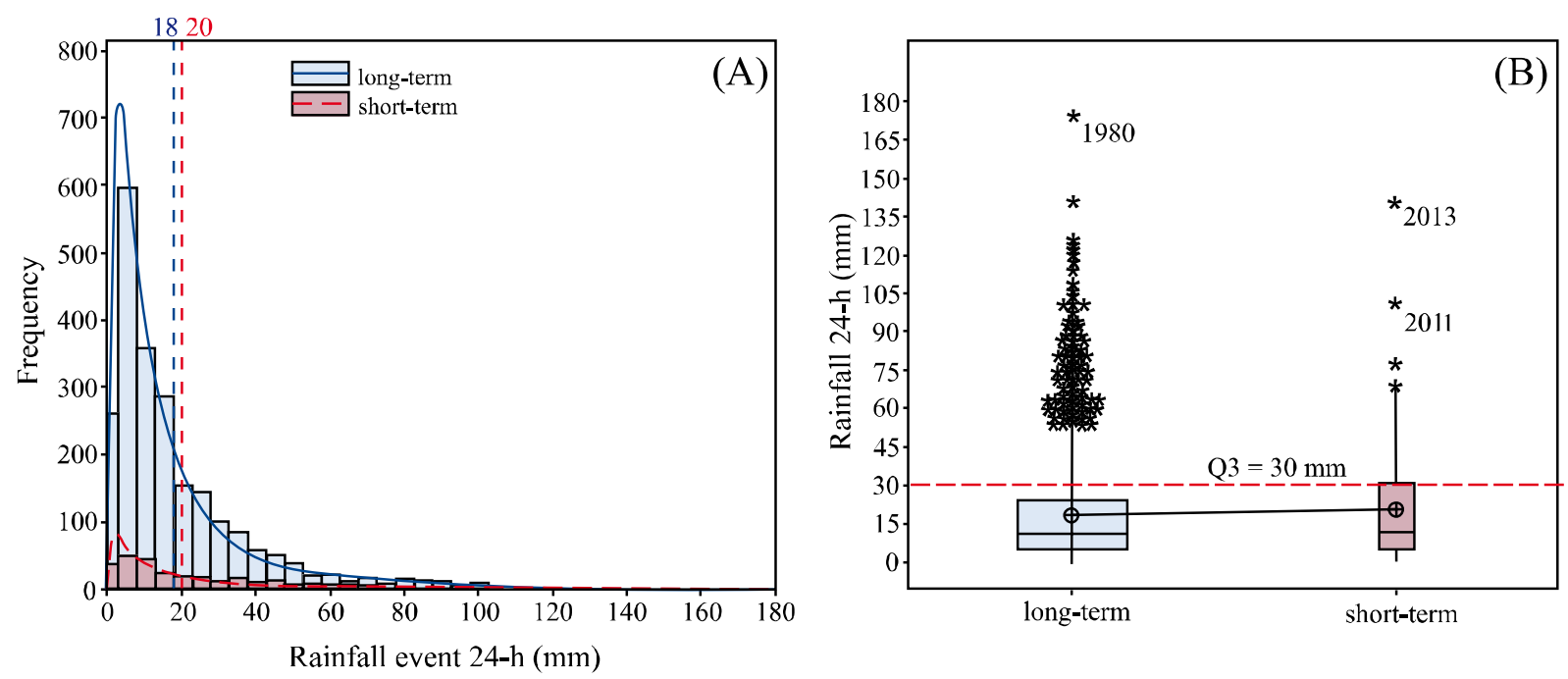
Table 3 - Descriptive statistics of the two hydrological series under investigation

\begin{tabular}{crccccccccc}
\hline Series & N & Mean & SD & Mín & Q1 & Median & Q3 & Max & Mode & Mode N \\
\hline Long-term (1974- 2013) & 2259 & 17.9 & 19.8 & 0.20 & 5.0 & 11.0 & 24.0 & 174.0 & 2 & 140 \\
Short-term (2009-2013) & 247 & 20.4 & 21.0 & 0.30 & 5.3 & 12.0 & 30.0 & 140.0 & 2 & 6 \\
\hline
\end{tabular}

Table 4 - Hydrological synthesis of the micro basins for the period (2009-2013) for $\mathrm{P} \leq 30 \mathrm{~mm}$

\begin{tabular}{|c|c|c|c|c|c|c|c|c|c|c|c|c|c|c|}
\hline \multirow{2}{*}{ Year } & \multirow{2}{*}{$\mathrm{TP}$} & \multirow{2}{*}{$\mathrm{NE}$} & \multicolumn{2}{|c|}{ Total Pe } & \multicolumn{2}{|c|}{$\mathrm{P} \leq 30 \mathrm{~mm}$} & \multicolumn{4}{|c|}{ CPDReg } & \multicolumn{4}{|c|}{ CPDThin } \\
\hline & & & CPDReg & CPDThin & $\mathrm{TP}$ & $\mathrm{NE}$ & $\mathrm{NE} P \mathrm{Pe}>0$ & $\mathrm{TP} P \mathrm{Pe}>0$ & $\mathrm{Pe}(\mathrm{mm})$ & $\mathrm{C}(\%)$ & $\mathrm{NE} P \mathrm{P}>0$ & $\mathrm{TP} \mathrm{Pe}>0$ & $\mathrm{Pe}(\mathrm{mm})$ & $\mathrm{C}(\%)$ \\
\hline 2009 & 1011 & 63 & 102.9 & 73.1 & 420.9 & 25 & 13 & 240.6 & 30.1 & 12.5 & 12 & 196.5 & 18.6 & 9.49 \\
\hline 2010 & 717 & 42 & 15.1 & 11.3 & 208.8 & 15 & 1 & 28.7 & 0.9 & 3.1 & 1 & 28.7 & 1.1 & 3.94 \\
\hline 2011 & 1417 & 68 & 187.5 & 143.3 & 487.2 & 35 & 10 & 192 & 23.0 & 11.9 & 8 & 172.9 & 12.7 & 7.32 \\
\hline 2012 & 807 & 38 & $*$ & * & 284.3 & 20 & 8 & 134.3 & 18.6 & 13.9 & 5 & 93.6 & 3.8 & 4.03 \\
\hline 2013 & 660 & 36 & 34 & 24 & 150.9 & 16 & 0 & 0 & 0 & 0 & 0 & 0 & 0 & 0 \\
\hline Total & 4613 & 247 & 339.5 & 251.7 & 1552.1 & 111 & 32 & 595.6 & 72.6 & - & 26 & 491.7 & 36.2 & - \\
\hline Mean & - & & & & - & - & - & - & & 10.4 & - & - & - & 6.2 \\
\hline
\end{tabular}

TP- total precipitation; NE - number of events; ${ }^{*}$ - sensor failure; Pe - effective precipitation (mm); C - runoff coefficient $(\%)$

result in greater soil water storage and contribute more effectively to the water available to vegetation. This shows the importance of such events for the rainfall regime in the region (ANDRADE et al., 2018; FANG et al., 2012). Therefore, investigations should be carried out that relate the characteristics of the rainfall events and the soil to the process of surface runoff in the CPD.

\section{Effective precipitation $(\mathrm{Pe})$}

The lowest values for effective precipitation (Pe) were registered in the micro basin of thinned CPD, with an accumulation of approximately $36 \mathrm{~mm}$, while in the micro basin of CPD under regeneration, the accumulated Pe was $72 \mathrm{~mm}$ (Table 4), corresponding to a difference of $50 \%$ between the two. This difference is expressed in the mean annual runoff coefficient $(\mathrm{C} \%)$. In the $\mathrm{CPD}$ under regeneration, the $\mathrm{C}$ was $10.43 \%$, while in the thinned $\mathrm{CPD}$, the $\mathrm{C}$ was $6.19 \%$. Since the two micro basins belong to the same class of soil (Table 1) and present physiographical similarities (Table 2), it is assumed that the difference in runoff results from the development of the herbaceous vegetation arising from thinning the tree species. The appearance of the herbaceous stratum promotes a dense layer of undergrowth (Figure 2B) (ANDRADE et al., 2018) and a rich superficial root system, as discussed in Asaye and Zewdie (2013). The undergrowth causes greater surface roughness (ANDRADE et al., 2018) and greater water infiltration in the soil through channels formed by the root system (PINHEIRO; COSTA; ARAÚJO, 2013). These processes result in a reduction in surface runoff (RAN et al., 2012; RODRIGUES et al., 2013) and greater soil moisture (ANDRADE et al., 2020; OWUOR et al., 2016). Plant cover that contributes to an increase in soil moisture favours greater system resilience to possible changes in climate.

\section{Annual scale}

At the level of the patterns under investigation (early, intermediate and late), there was no predominance of one pattern over another, since the number of events occurring in each pattern varied from 8 to 13 in the CPD under regeneration, and from 7 to 11 in the thinned CPD (Tables 5 and 6). It is believed that the lack of a defined trend for a pattern may be due to the small number of investigated events. Although the early pattern was the only one present in each year that runoff occurred, it was the rainfall pattern that generated the lowest annual Pe. The rainfall events that presented an intermediate pattern generated the greatest runoff depths and were responsible for $54 \%$ and $48 \%$ of the Pe in the CPDReg and CPDThin micro basins respectively (Table 5 and 6 ); the late pattern showed the second-largest runoff (Tables 5 and 6). The Pe values therefore had the following order: Intermediate pattern $>$ late pattern $>$ early pattern.

These results suggest that in vertic soils the rainfall pattern is not the main determining factor in the occurrence of effective precipitation or its extent. It is believed that this behaviour is due to the occurrence of existing microcracks in soils rich in 2:1 clay. In early-pattern rainfall events (maximum intensity at the start of the rainfall), the micro-cracks have not yet sealed and act as preferential runoff pathways (SANTOS et al., 2016), promoting 
Table 5 - Hydrological synthesis of the CPD under regeneration for $\mathrm{P} \leq 30 \mathrm{~mm}$ for the different rainfall patterns

\begin{tabular}{|c|c|c|c|c|c|c|c|c|c|c|c|c|c|}
\hline \multirow[b]{2}{*}{ Year } & \multirow[b]{2}{*}{ Annual P } & \multicolumn{4}{|c|}{ Early Pattern } & \multicolumn{4}{|c|}{ Intermediate Pattern } & \multicolumn{4}{|c|}{ Late Pattern } \\
\hline & & $\begin{array}{c}\text { Events } p / \\
P e>0\end{array}$ & Total P & $\begin{array}{l}\mathrm{Pe} \\
(\mathrm{mm})\end{array}$ & $\begin{array}{l}\mathrm{C} \\
(\%)\end{array}$ & $\begin{array}{c}\text { Events } \mathrm{p} / \\
\mathrm{Pe}>0\end{array}$ & Total P & $\mathrm{Pe}(\mathrm{mm})$ & $\mathrm{C}(\%)$ & $\begin{array}{c}\text { Events } \mathrm{p} / \\
\mathrm{Pe}>0\end{array}$ & Total P & $\mathrm{Pe}(\mathrm{mm})$ & $\mathrm{C}(\%)$ \\
\hline 2009 & 1011 & 6 & 92.1 & 8.77 & 9.5 & 3 & 68.5 & 3.77 & 5.5 & 4 & 80.0 & 17.59 & 21.98 \\
\hline 2010 & 717 & 1 & 28.7 & 0.89 & 3.1 & 0 & & 0 & 0 & 0 & & 0 & 0 \\
\hline 2011 & 1417 & 1 & 27.9 & 0.98 & 3.5 & 5 & 102.5 & 21.22 & 20.7 & 4 & 61.5 & 0.81 & 1.31 \\
\hline 2012 & 807 & 3 & 53.8 & 4.19 & 7.8 & 5 & 80.5 & 14.46 & 17.9 & 0 & & 0 & 0 \\
\hline 2013 & 660 & 0 & & 0 & 0 & 0 & & 0 & 0 & 0 & & 0 & 0 \\
\hline Total & 4613 & 11 & 202.5 & 14.83 & - & 13 & 251.5 & 39.45 & & 8 & 141.5 & 18.40 & \\
\hline Mean & - & - & & - & 7.3 & - & & - & 15.7 & - & & - & 13.0 \\
\hline
\end{tabular}

$\mathrm{Pe}=$ effective precipitation $(\mathrm{mm}) ; \mathrm{C}=$ mean runoff coefficient for events that generated runoff $(\%)$

Table 6 - Hydrological synthesis of the thinned CPD for $\mathrm{P} \leq 30 \mathrm{~mm}$ for the different rainfall patterns

\begin{tabular}{|c|c|c|c|c|c|c|c|c|c|c|c|c|c|}
\hline \multirow[b]{2}{*}{ Year } & \multirow{2}{*}{$\begin{array}{c}\text { Annual } \\
\mathrm{P}\end{array}$} & \multicolumn{4}{|c|}{ Early Pattern } & \multicolumn{4}{|c|}{ Intermediate Pattern } & \multicolumn{4}{|c|}{ Late Pattern } \\
\hline & & $\begin{array}{l}\text { Events } \\
\text { p/Pe>0 }\end{array}$ & Total P & $\mathrm{Pe}(\mathrm{mm})$ & $\mathrm{C}(\%)$ & $\begin{array}{l}\text { Events } \\
\mathrm{p} / \mathrm{Pe}>0\end{array}$ & Total P & $\operatorname{Pe}(\mathrm{mm})$ & $\mathrm{C}(\%)$ & $\begin{array}{l}\text { Events } \\
\mathrm{p} / \mathrm{Pe}>0\end{array}$ & Total P & $\mathrm{Pe}(\mathrm{mm})$ & $\mathrm{C}(\%)$ \\
\hline 2009 & 1011 & 6 & 92.1 & 5.70 & 5.5 & 2 & 44.4 & 2.09 & 5.3 & 4 & 60 & 10.86 & 12.02 \\
\hline 2010 & 717 & 1 & 28.7 & 1.13 & 3.9 & 0 & & 0 & 0 & 0 & & 0 & 0 \\
\hline 2011 & 1417 & 1 & 27.9 & 0.05 & 0.2 & 4 & 88.6 & 12.21 & 14.7 & 3 & 56.4 & 0.41 & 0.73 \\
\hline 2012 & 807 & 3 & 43.4 & 0.77 & 1.7 & 2 & 50.3 & 3.01 & 5.5 & 0 & & 0 & 0 \\
\hline 2013 & 660 & 0 & & 0 & 0 & 0 & & 0 & 0 & 0 & & 0 & 0 \\
\hline Total & 4613 & 11 & 192.1 & 7.65 & - & 8 & 183.3 & 17.31 & - & 7 & 116.4 & 11.27 & - \\
\hline Mean & - & - & & - & 4.0 & - & & - & 9.4 & - & & - & 9.7 \\
\hline
\end{tabular}

greater water infiltration in the soil (PATHAK et al., 2013). On the other hand, when the maximum rainfall intensity occurs in the middle third or final third of the event, the micro-cracks have already sealed or are close to sealing, which may reduce the effect of the preferential pathways and promote greater Pe.

Although the two micro basins showed the same response trend to the rainfall pattern, it can be seen that the CPD under regeneration (Table 5) had Pe values that were $94 \%, 128 \%$ and $34 \%$ greater than those registered in the thinned CPD for the early, intermediate and late rainfall patterns respectively (Table 6). When the runoff coefficients $(\mathrm{C} \%)$ are compared between the two micro basins in relation to the three rainfall patterns (Tables 5 and 6), a lower value for $\mathrm{C}$ can be seen in the micro basin with thinned CPD for all patterns, in the proportions: early $(46 \%)$, intermediate $(39 \%)$ and late $(25 \%)$. These results show that undergrowth reduces runoff in all the rainfall patterns, with a greater effect on the early pattern. The undergrowth promotes greater initial abstraction (GUAN; SILLANPÄ̈̈; KOIVUSALO, 2016; OWUOR et al., 2016) and reduces the speed of surface runoff (JOST et al., 2012; LIU et al., 2014).

\section{Daily scale}

On an event scale of 24 hours, both micro basins had smaller rainfall depths for the early rainfall pattern (Figure 5A). Therefore, the events where $\mathrm{P} \leq 30 \mathrm{~mm}$, and the peak of greatest intensity was registered at the start of the rainfall, generated less runoff than rainfall events with the peaks of greatest intensity registered during the middle third or final third of the event. When the maximum intensity is registered during the first third of the event, the soil displays greater retention capacity, since it is not yet saturated nor has the rainfall intensity exceeded the instantaneous infiltration rate of the soil (MU et al., 2015). Another physical process that may explain the smaller runoff generated by the early pattern under both types of plant cover is the high level of water absorption resulting from the process of expansion and compression of the clay. This process gives rise to the formation of cracks that function as preferential pathways for the runoff (PATHAK et al., 2013; SANTOS et al., 2016), as discussed above in the sub-item, Annual scale.

The smallest runoff or effective precipitation was registered in the thinned CPD, irrespective of the 
Figure 5 - Relationship between effective precipitation and rainfall for $\mathrm{P} \leq 30 \mathrm{~mm}$ for the early (A), intermediate (B) and late (C) patterns from 2009-2013
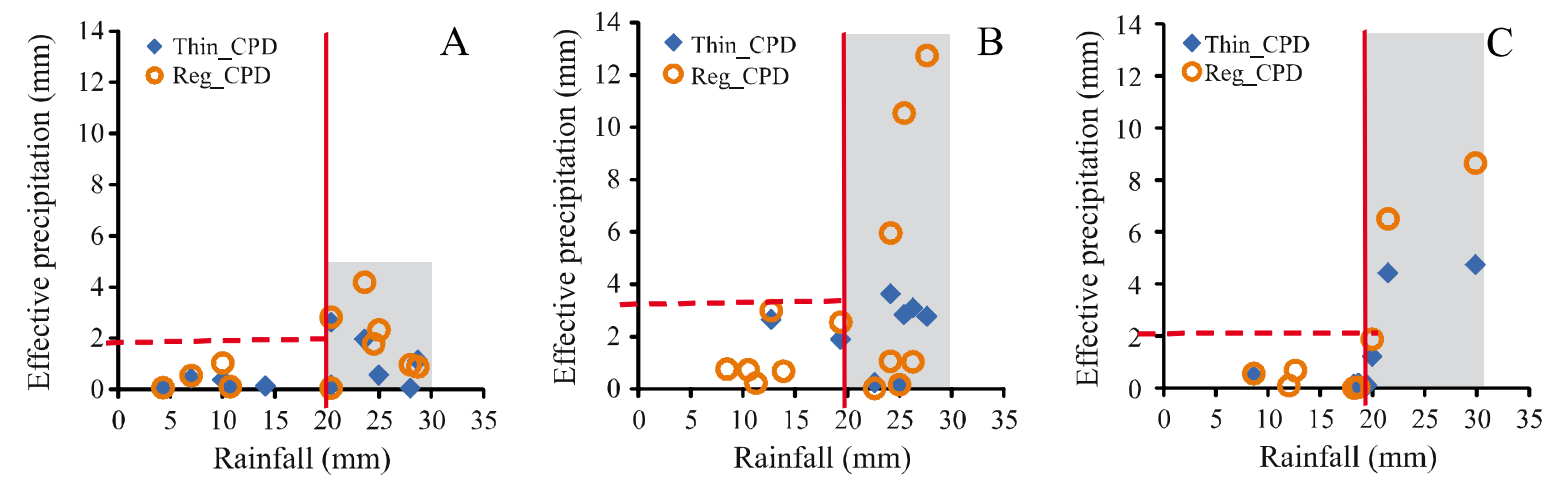

rainfall pattern (Figure 5). As the micro basins have the same particle-size distribution and soil mineralogy (Table 1), as well as similar physical characteristics (Table 2), this reduction in $\mathrm{Pe}$ is attributed to the greater density of the undergrowth, a result of thinning. Another point to be considered is that the greatest differences in Pe generated by the micro-basins occurred where $\mathrm{P}>20$ $\mathrm{mm}$ (Figure 5). This difference shows that undergrowth is more effective in reducing the runoff from events of greater rainfall depth (ANDRADE et al., 2018). Regardless of the rainfall pattern and management applied to the micro-basins (CPD under regeneration and thinned CPD), rainfall of $<20 \mathrm{~mm}$ generated runoff of less than $3 \mathrm{~mm}$. This behaviour can be explained by the clay texture of the soil in the two micro basins.

When Pe events are related to maximum intensity over 30 minutes (I30 $\mathrm{mm} \mathrm{h}^{-1}$ ) for the different rainfall patterns (Figure 6), the same trend shown by rainfall depth can be seen, i.e. the greatest effective precipitation occurred for the intermediate and late patterns. It is understood that the greater runoff depths for these patterns are due to the peak of greatest intensity occurring when the soil is saturated or close to saturation and showing less infiltration capacity.

Events with an intensity of less than or equal to $25 \mathrm{~mm} \mathrm{~h}^{-1}$, and with an early pattern, generated runoff depths which were always less than $2 \mathrm{~mm}$ in each micro-basin (Figure 6A). It should also be noted that for the intermediate pattern (Figure 6B), events with an intensity of up to $17 \mathrm{~mm} \mathrm{~h}^{-1}$ produced no runoff in the micro-basin with a predominance of undergrowth (thinned CPD).

The undergrowth contributes to greater infiltration, reducing runoff (ANDRADE et al., 2018). After exceeding this intensity threshold $\left(17 \mathrm{~mm} \mathrm{~h}^{-1}\right)$ for the intermediate and late rainfall patterns, the greatest runoff depths were registered in both micro basins for the intermediate pattern, with a maximum value of $12.7 \mathrm{~mm}$. It is believed that the greater Pe generated by the intermediate- and early-pattern rainfall, contrary to expectations, is due to the spatial scale of the microbasins ( $<2 \mathrm{ha})$. The assumed hypothesis was that very small areas might not show any effect from the time of maximum intensity due to the short period between the beginning of the event and the steady-state condition of the runoff process. It is necessary to carry out studies that consider the scale effect and the pattern of rainfall events in order to confirm or reject the above hypothesis.

Analysing the relationship between effective precipitation and consecutive dry days (CDD), it can be seen that the greatest runoff was found in the absence of CDD (Figure 7). The largest runoff depths were registered for the intermediate pattern (with a maximum value of $12.7 \mathrm{~mm}$ ) for a CDD of 0 , total precipitation of $27.6 \mathrm{~mm}$ and $\mathrm{I} 30$ of $56.0\left(\mathrm{~mm} \mathrm{~h}^{-1}\right)$, followed by the late and early patterns.

The effect of CDD on runoff generation is apparent in the three rainfall patterns (Figure 7). With the occurrence of three CDD, no effective precipitation was registered for the early or late patterns. However, for the intermediate pattern, runoff was registered for between three and four CDD, but with a depth of less than $2.5 \mathrm{~mm}$. The non-occurrence of runoff after four CDD is due to the high retention capacity of the type 2:1 clay found in both areas, promoting greater water retention (PATHAK et al., 2013). The events that generated runoff on those days had a mean rainfall of $22.3 \mathrm{~mm}$ and a mean I30 of $29.3\left(\mathrm{~mm} \mathrm{~h}^{-1}\right)$. Researchers such as Santos et al. (2016), have shown that in a tropical semi-arid region with vertic soils, runoff does not occur where the CDD>5 and the rainfall depth $<40 \mathrm{~mm}$. 
Figure 6 - Relationship between effective precipitation and maximum intensity over 30 minutes (I30 $\left.\mathrm{mm} \mathrm{h}^{-1}\right)$ for $\mathrm{P} \leq 30 \mathrm{~mm}$ for the early (A), intermediate (B) and late (C) patterns from 2009-2013
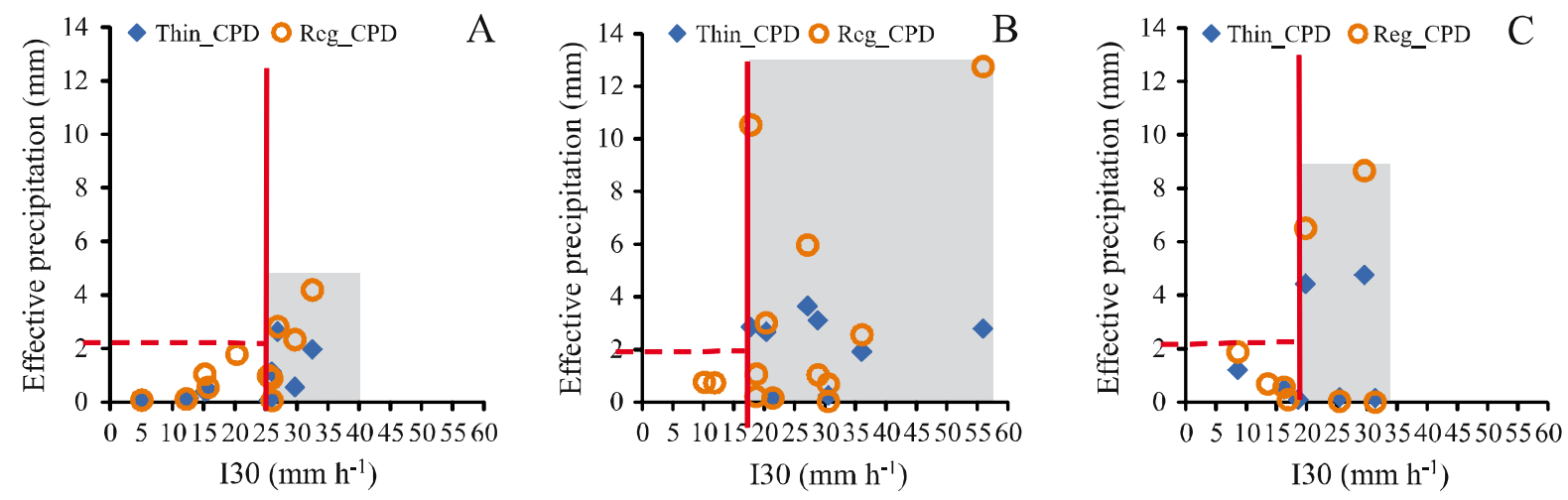

Figure 7 - Relationship between effective precipitation and consecutive dry days for $\mathrm{P} \leq 30 \mathrm{~mm}$ for the early (A), intermediate (B) and late (C) patterns from 2009-2013

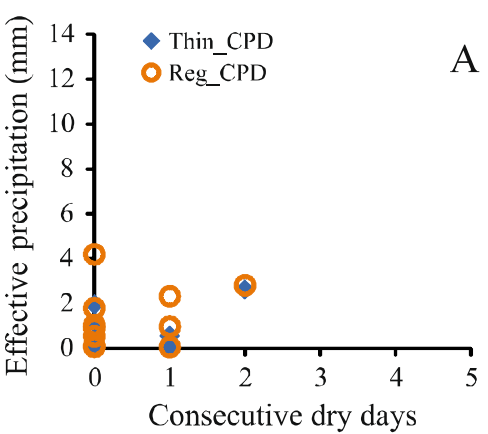

Consecutive dry days
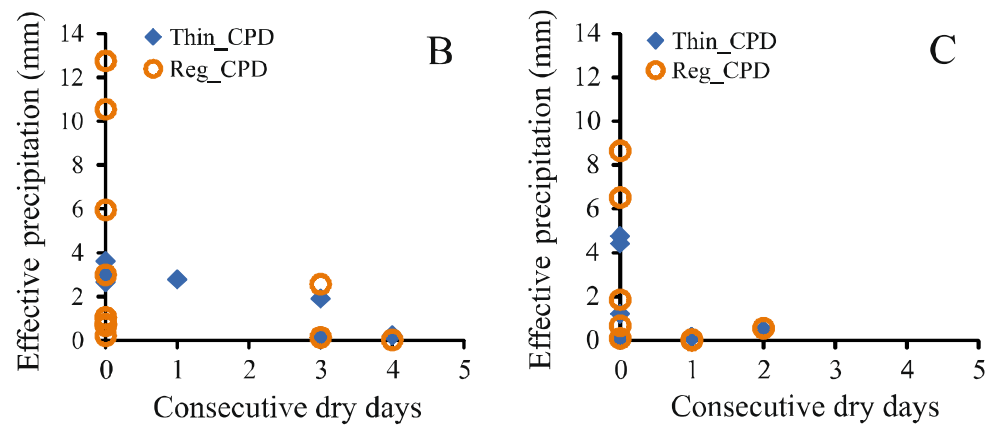

\section{CONCLUSIONS}

1. A series of 247 24-hour rainfall events proved to be statistically representative in investigating hydrological processes in the semi-arid region of Brazil, compared to a long series of 2,259 events. These results aid hydrological studies in regions where the historical series of daily data are small;

2. Irrespective of the pattern, rainfall with an intensity of less than $17 \mathrm{~mm} \mathrm{~h}^{-1}$ generated effective precipitation with small depths $(<2 \mathrm{~mm})$. The lowest effective precipitation was registered for the plant cover of thinned CPD regardless of the rainfall pattern, both on an annual scale and per event;

3. The occurrence of 3 or $4 \mathrm{CDD}$ is enough for events of $<30 \mathrm{~mm}$ not to generate runoff, due to the appearance of micro-cracks formed in vertisols during the drying process. The intensity of the rainfall that occurs in the middle or final third of the rainfall event is not the main determinant of effective precipitation $(\mathrm{Pe})$. It is assumed that the process of expansion and contraction of vertic soils is the determining factor for the start of Pe in areas with a water source (micro-basins $<2 \mathrm{ha}$ ) in the CPD.

\section{REFERENCES}

ALMEIDA, C. L.; OLIVEIRA, J. G. B.; ARAÚJO, J. C. Impacto da recuperação de área degradada sobre as respostas hidrológicas e sedimentológicas em ambiente semiárido. Water Resources and Irrigation Management, v. 1, n. 1, p. 39-50, 2012.

ANDRADE, E. M. et al. Ecohydrology in a Brazilian tropical dry forest: thinned vegetation impact on hydrological functions and ecosystem services. Journal of Hydrology: Regional Studies, v. 27, p. 100649, 2020.

ANDRADE, E. M. et al. Hydrological responses of a watershed to vegetation changes in a tropical semiarid region. Revista Caatinga, v. 31, n. 1, p. 161-170, 2018.

ARAÚJO FILHO, J. A. Manipulação da vegetação lenhosa da caatinga para fins pastoris. 1. ed. Sobral: EMBRAPA-CNPC, 1992. 18 p. (Circular Técnica, 11). 
ASAYE, Z.; ZEWDIE, S. Fine root dynamics and soil carbon accretion under thinned and un-thinned Cupressus lusitanica stands in, Southern Ethiopia. Plant and soil, v. 366, n. 1/2, p. 261$271,2013$.

BARTON, I. F. Georgius Agricola's contributions to hydrology. Journal of Hydrology, v. 523, p. 839-849, 2015.

BRASIL, J. B. et al. Characteristics of precipitation and the process of interception in a seasonally dry tropical forest. Journal of Hydrology: Regional Studies, v. 19, p. 307-317, 2018.

CAMARASA-BELMONTE, A. M. Flash floods in Mediterranean ephemeral streams in Valencia Region (Spain). Journal of Hydrology, v. 541, p. 99-115, 2016.

FANG, N. F. et al. The effects of rainfall regimes and land use changes on runoff and soil loss in a small mountainous watershed. Catena, v. 99, p. 1-8, 2012.

FIGUEIREDO, J. V. et al. Runoff initiation in a preserved semiarid Caatinga small watershed, Northeastern Brazil. Hydrological Processes, v. 30, n. 13, p. 2390-2400, 2016.

GUAN, M.; SILLANPÄÄ, N.; KOIVUSALO, H. Storm runoff response to rainfall pattern, magnitude and urbanization in a developing urban catchment. Hydrological Processes, v. 30, n. 4, p. $543-557,2016$.

GUERREIRO M. J. S. et al. Long-term variation of precipitation indices in Ceará State, Northeast Brazil. International Journal of Climatology, v. 33, n. 14, p. 2929-2939, 2013.

JOST, G. et al. A hillslope scale comparison of tree species influence on soil moisture dynamics and runoff processes during intense rainfall. Journal of Hydrology, v. 420, n. 2, p. 112-124, 2012.

LIMA, C. A. et al. Characteristics of rainfall and erosion under natural conditions of land use in semiarid regions. Revista Brasileira de Engenharia Agrícola e Ambiental, v. 17, n. 11, p. 1222-1229, 2013.

LIU, R. et al. Runoff characteristics and nutrient loss mechanism from plain farmland under simulated rainfall conditions. Science of the Total Environment, v. 468, p. 1069-1077, 2014.

MARENGO, J. A.; TORRES, R. R.; ALVES, L. M. Drought in Northeast Brazil - past, present, and future. Theoretical and Applied Climatology, v. 129, n. 3/4, p. 1189-1200, 2017.

MEHL, H. U. et al. Caracterização de padrões de chuvas ocorrentes em Santa Maria (RS). Revista Brasileira de Ciência do Solo, v. 25, n. 1, p. 475-483, 2001.

MU, W. et al. Effects of Rainfall Intensity and Slope Gradient on Runoff and Soil Moisture Content on Different Growing Stages of Spring Maize. Water, v. 7, n. 6, p. 2990-3008, 2015.

OWUOR, S. O. et al. Groundwater recharge rates and surface runoff response to land use and land cover changes in semi-arid environments. Ecological Processes, v. 5, n. 1, p. 16, 2016.
PALÁCIO et al. Emergy evaluation of semiarid watersheds under different management strategies. Transactions of the ASABE American Society of Agricultural and Biological Engineers, v. 56, n. 6, p. 1357-1363, 2013.

PATHAK, P. et al. Hydrological behavior of Alfisols and Vertisols in the semi-arid zone : implications for soil and water management. Agricultural Water Management, v. 118, p. 1221, 2013.

PENG, T.; WANG, S. J. Effects of land use, land cover and rainfall regimes on the surface runoff and soil loss on karst slopes in southwest China. Catena, v. 90, p. 53-62, 2012.

PEREIRA JÚNIOR, L. R. et al. Carbon stocks in a tropical dry forest in Brazil. Revista Ciência Agronômica, v. 47, n. 1, p. 3240, 2016.

PETRIE, M. D.; COLLINS, S. L.; LITVAK, M. E. The ecological role of small rainfall events in a desert grassland. Ecohydrology, v. 8, n. 8, p. 1614-1622, 2015.

PINHEIRO, E. A. R.; COSTA, C. A. G.; ARAÚJO, J. C. Effective root depth of the Caatinga biome. Journal of Arid Environments, v. 89, p. 1-4, 2013.

RAN, Q. et al. Experimental study of the impact of rainfall characteristics on runoff generation and soil erosion. Journal of Hydrology, v. 424, n. 2, p. 99-111, 2012.

REYNOLDS, J. F. et al. Natural and human dimensions of land degradation in drylands: causes and consequences. In: REYNOLDS, J. F. et al. Terrestrial ecosystems in a changing world. 2007. p. 247-257.

RODRIGUES, J. O. et al. Respostas hidrológicas em pequenas bacias na região semiárida em função do uso do solo. Revista Brasileira de Engenharia Agrícola e Ambiental, v. 17, n. 13, p. 312-318, 2013.

SANTOS, J. C. N. et al. Effect of dry spells and soil cracking on runoff generation in a semiarid micro watershed under land use change. Journal of Hydrology, v. 541, p. 10571066, 2016.

SANTOS, J. C. N. et al. Effect of rainfall characteristics on runoff and water erosion for different land uses in a tropical semiarid region. Water Resource Management, v. 31, n. 1, p. $173-185,2017$.

UNITED NATIONS ENVIRONMENT MANAGEMENT GROUP. Global Drylands: a UN system-wide response. UNEP/ UN, 2011. 132 p.

UNITED NATIONS ENVIRONMENT PROGRAMME. The Global Environment Outlook 4: environment for development. Nairobi: UNEP, 2007.

WOLDESENBET, T. A. et al. Catchment response to climate and land use changes in the Upper Blue Nile sub-basins, Ethiopia. Science of the Total Environment, v. 644, p. 193-206, 2018. 